\title{
Open "Laicity" and Secularity versus Ideological Secularism: Lessons from Switzerland
}

\author{
DENIS MÜLLER \\ Université de Lausanne, Lausanne, Switzerland
}

\begin{abstract}
In order to avoid both religious intolerance and religious indifference, we need to develop a positive notion of an open laicity or secularity that permits us to respect our religiously plural as well as secular contemporary situation. Open laicity or secularity is the practical and political consequence of a Protestant theology and spirituality. It represents a critical answer to the disaster of secularism and laicism. Most of the difficulties in the discussion between traditionalist Christians (Orthodox, Catholic, or Evangelical!) and modern, critical Christians (Protestant, Catholic, and maybe some Orthodox too!) come from a confusion between the danger of secularism and laicism, that this article criticizes very deeply, and the positive reality of a secular world, grounded in the very biblical and theological understanding of a created world, in which God has given to all human beings the task to behave in a rational, responsible, creative, and respectful way.
\end{abstract}

Keywords: bioethics, Christian ethics, churches, laicity, plurality, secularism, secularity, universality

\section{HOW SWISS IS CHRISTIAN BIOETHICS IN SWITZERLAND?}

When one looks at the situation of Christian bioethics in Switzerland, one encounters an objective difficulty. First, there are official positions of the churches, and secondly there are the concrete and various ways individual Christian bioethicists intervene in the public ethical debates. On the general level of church pronouncements, two main positions can be described: a tra-

Address correspondence to: Denis Müller, Faculté de théologie et de sciences des religions, Université de Lausanne, CH-1015 Lausanne, Switerzland. E-mail: denis.muller@unil.ch.

(c) The Author 2009. Published by Oxford University Press, on behalf of The Journal of Christian Bioethics, Inc. All rights reserved. For permissions, please e-mail: journals.permissions@oxfordjournals.org 
ditional, classical approach of life ethics, mostly represented by the Catholic Church and by the congregations and communities belonging to the evangelical side of Protestantism. This approach fights for the rights of every embryo, to which it attributes personal and spiritual life, it defends the traditional vision of marriage and family (and therefore strongly opposes every positive recognition of homosexual experience or partnership), and it adopts a restrictive approach against all attempts to introduce individual choice in the realm of assisted suicide and euthanasia. On the other side, mainly represented by the reformed churches and their common engagement in the so-called Federation of the Protestant Churches in Switzerland, one finds a more liberal position, not necessarily in all these cases, but willing to accept the challenge of a open, critical, and controversial discussion inside the churches and among the Christian believers themselves. The very difficulty of distinguishing these two approaches reveals that their opposition is not a frontal one, as though they arose from doctrinal and substantial disagreements, but that their disagreement reflects more a different understanding of the connections between public sphere and private convictions as well as between the State and the organized churches themselves. But we must also admit that behind these procedural and methodological differences lies without doubts a more substantial issue based on a theological and spiritual disagreement about the relations between faith, human reality, and secular, modern society.

That basic disagreement explains also, in my view, why individual Christian bioethicists (not only Protestant but also some Catholic ones) do not simply represent and repeat the official positions of their own churches or communities, but understand themselves, and are very often understood as well, as committed and responsible intellectuals, who try in an apologetic and public way to introduce the point of view of faith and Christianity on ethical problems in the open discourse of society.

\section{WHY A CONSERVATIVE THEORY OF CHRISTIAN BIOETHICS IS NOT APPROPRIATE IN THIS MODERN CONTEXT?}

Once one recognizes the importance of this situation, one also begins to understand why the traditional approach to different meanings of "theology" (see Engelhardt, 2007), while seeming so impressive on a analytical level, completely misses the point of our real situation in European and probably also in American modern contemporary society. ${ }^{1}$ Take for instance the beautiful and subtle (traditional) distinctions between the five senses of theology in the coherent but also very circular and narrowly subjective reconstruction of Engelhardt in his answer to my own text (Engelhardt, 2007, 32ss). The hierarchy of these five senses, at a first glance, seems to be absolutely logical and stringent. ${ }^{2}$ But analyzed in the context of Engelhardt's more general strategy, this hierarchy instead comes out as a very defensive and self-justifying affirmation of the truth of his own particular (i.e., Orthodox) understanding of theology, 
as opposed to all other possible (i.e., Protestant and Catholic) understandings of theology. For example, it is not true, in my view, that the adoption, for a while, of the forth and the fifth senses of theology implies a denial of the truths of the three first senses. Personally, as a modern Reformed theologian, I see no necessary opposition between the use of a philosophy of religion in a theologically structured argumentation and a Trinitarian approach. Of course, I know (and I could agree with Engelhardt on this aspect of the question) that a majority of so-called "liberal" theologians have had traditional difficulties with Trinitarian theology. But even authors, such as Schleiermacher and Tillich, for instance, have tried to account for the question of the Trinity; the fact that they did not accept the traditional (Catholic, Orthodox, and Reformed!) theology of the Trinity in all their nuances and internal contradictions does not mean that they refused to think of it. The Trinitarian character of a good theology, Catholic, Orthodox, or Protestant, has nothing to do with a person's ability to repeat in a scholarly way what the tradition or the Fathers or even the Ecumenical Councils have said and thought. Instead, it has to do with the capacity of contemporary theology to give a meaningful and convincing account of the meaning of the Trinity for human beings and today's world. In this sense, the hierarchical distinctions of the five senses of theology is a intellectual and spiritual catastrophe for human beings of today and for the world in which we live as Christians and churches. It has the consequences of spiritually isolating individuals yearning for hope, meaning, and consolations in their daily life and profession-from the traditions and practices of the churches; churches would then be understood as nice and pretty clubs of religions and moral friends.

\section{MORE ABOUT SWITZERLAND}

Switzerland, like most of the Western European countries and nations, has become more and more secular. One of the most striking examples has been the lengthy discussion on the Preamble of the Swiss Constitution. Let us compare the old text of 1874 with the new text from the end of the twentieth century.

Preamble of 1874

In the Name of Almighty God, the Swiss Confederation, with the intent of strengthening the alliance of the Confederates and of maintaining and furthering the unity, strength and honour of the Swiss nation, has adopted the following Federal Constitution.

Preamble of 1999

In the name of God Almighty! 
We, the Swiss People and Cantons,

whereas, we are mindful of our responsibility towards creation;

resolve to renew our alliance to strengthen liberty and democracy, independence and

peace in solidarity and openness towards the world;

are determined to live our diversity in unity respecting one another;

are conscious of our common achievements and our responsibility towards future

generations;

and know that only those remain free who use their freedom, and that the strength of

a people is measured by the welfare of the weakest of its members;

now, therefore, we adopt the following Constitution.

In 1999, the old traditional invocation "God Almighty" was retained, in opposition to a secular trend shared by many critics to renounce it. The old version of the Preamble was based on an implicit, more ancient, and classical theology of covenant (going back to Calvin and Zwingli and developed by Althusius and the Protestant orthodoxy in the seventeenth century), by bringing together the political notion of Alliance (foedus, Bund, in German) with the idea of the Almighty God contracting a covenant with all humanity in general and Switzerland in particular. The new version, by contrast, tries to harmonize two opposite conceptions of nation, the modern concept being now based on the will of the citizens. Switzerland, in this perspective, is a "Willensnation," a nation resulting from the committed and responsible will of all citizens. The older, nationalistic conception of "unity, strength, and honor" of the Swiss nation (see the preamble of 1874) is transformed into a radically new, cosmopolitan, and universalistic conception of a open nation, whose understanding of alliance is clearly orientated toward "peace, justice, and safeguarding creation," in the sense of the ecumenical formulation of the European Conference of Basel in 1989. Of course, in this very complex elaboration of a new constitutional synthesis, a tension remains between the traditional idea of nation and the (post-Kantian) reinterpretation of nations as open entities guided by the ethical vision of a universal kingdom of ends.

Now, what does all that mean for the situation of Christian bioethics in Switzerland? As Switzerland is not an island (pace the conservative majority of the Swiss people today), it shares the political, ethical, and religious destiny of modern Western Europe. If one interprets the shift from the classical Protestant theology of the covenant to the contemporary understanding of Switzerland in its secular Constitution in a nostalgic way, one could be tempted to look at it as a desertion, and even a betrayal, of the Christian 
background of the biblical theology of covenant. In my opinion, on the contrary, this shift should be understood as a positive integration of the biblical perspective into the modern, secular, and plural context of the public political discussion. The question is not to forsake or betray the heritage of Christianity, but how to give it a chance to be understood and integrated into a new context. This is what I mean by a responsible theology: one that refuses being reduced to a mere repetition of the intellectual structures of the theologies of the past but that tries with determination, courage, and creativity to think and to formulate the meaning of the eternal truth of the Gospel in today's world - that is, in the modern, secular, plural, and controversial world of the twenty-first century.

\section{CHURCHES AND STATE}

In contrast to France (with the exception of Alsace, where the German model of State-Churches, Landeskirchen is still dominant), Switzerland does not know a general separation of Churches and State (see Bühler, 2007). This is a result of the fact that the Swiss Confederation is organized in "cantonal States" (the 23 Swiss Cantons), each of which has different historically evolved political solutions for the status of churches and religions. The greatest separation of State and religions is observed in cantons like Geneva and Neuchâtel, but even here the separation is not absolute. In the German-speaking part of Switzerland, where the majority of the Swiss population lives, German model still dominates, at least at the constitutional level, because this model has been more and more criticized during the last forty years.

Let us specify that we speak here of separation and union in a formal and organizational way. The fact that in Geneva and Neuchâtel the Churches are separated from the State does not necessarily mean that these two cantons are less open to the practice of religions. It only means that the citizens of these cantons decided that a formal separation allows concrete arrangements between State, Churches, and religions, in respect of both religious and political freedom. A certain collaboration exists also in these cantons between the State and the recognized Churches or communities based on transparency and independence. The Churches have to respect the various ways in which different cantons regulate their financing (i.e., through voluntary Church taxes in Geneva and Neuchatel, or in automatically imposed Church taxes in other cantons, of which atheists however can demand to be freed). That is, they have to respect the political and financial framework of the State, but the State has no right at all to interfere with belief and religious practices, as long, of course, as these practices do not contradict the constitution and the fundamental rights of the citizen.

But the growing secularization of the last decades, even in the cantons previously organized on the model of State-Church, like Vaud (whose capital city is Lausanne), has recently produced new regulations. The Protestant 
Church has lost its privileged status of the only State-Church. It must now share with other Churches or religions, especially with the Roman Catholic Church and with the Jewish community. Every religious community has the possibility to apply for State recognition, and surely the next steps in this direction will concern the different Islamic communities, which are multiplying in our country.

Even if the word "laicity"3 (laïcité) seems to remain peculiar to the Frenchspeaking cantons of Switzerland because of their proximity to the French situation (but the notion exists also in Southern Europe, for instance in Italy, see Badini Confalonieri, 2002), it is now clear that in all Switzerland, like in all Western Europe and North America, we live de facto in a secular and plural situation. That means that the question of the status of churches and religious communities must be solved in a context of political laicity. The problem with laicity, as it is also the case in English with words like secularity, lays in the fact that one can understand it in two very different senses, a negative and a positive or at least more neutral way. In the negative sense, laicity is linked with antireligious or anticlerical views and tends to become synonymous of active, negative, and aggressive secularism. In the positive sense, laicity stands for a neutral, political framework, where all convictions, religious or nonreligious, can live together in mutual respect. Some authors therefore draw a conceptual distinction between closed laicity (negative sense) and open laicity (positive sense).

Today we live in a very secular country, but with a strong sense both of freedom of religion and freedom of expression. Religious practice has become more and more free and individualized. But we are divided between fascination and disenchantment (see Campiche, 2004). And Christianity is no longer the only player: time has come for pluri- and interreligious forms of religious practices and rituals.

As we can all know and read, the sociological and theoretical debate on secularization is immense and very controversial, from Max Weber to Hans Blumenberg or Marcel Gauchet through Friedrich Gogarten, the Protestant German theologian, who, in the second part of the twentieth century, established positive links between the Christian understanding of the created world, the human being as responsible creature, and the secularized world of modernity (Gogarten, 1953, 1987). Following this author, "secularization" here will not be understood in a naive sense, as if the religions were all dying or collapsing. Secularization, as rigorously separated from secularism, represents on the contrary the historical and social process on the basis of which one can understand and interpret the normative and positive notion of laicity or secularity. To demonstrate the intimate link between secularization, laicity, and Christianity, a very detailed argument would be required. It would have to expose the theoretical coherence, without any confusion or syncretism, between the positive sense of secularity and the specific meaning of Christian freedom understood in dialectical distance and proximity to 
the modern values of freedom and justice. At the end of such a demonstration, if successful, one could also refute the affirmations of Engelhardt, when he globally accuses modern theology (both Catholic and Protestant) of merely "recasting" Christianity as a whole (its doctrine and its ethics) "in the image and likeness of contemporary secular philosophical and moral concerns" (Engelhardt, 2007, 44). His accusation is reminiscent of the classical objections of Karl Barth not only to Protestant liberal theologians but also to the Roman Catholic thesis of an analogia entis. Engelhardt is also very much in favor of the traditional, conservative evangelical theologians, "the fundamentalist Protestants" (ibid., 44) as he naively calls them. The whole of his demonstration confirms us in the impression that Engelhardt not only has a dogmatical preference for the traditional Christianity in its more traditionalist sense but also that his own theological choices are much more influenced by an antimodern (and therefore culturally quite modern!) understanding of theology, objectively necessarily linked with the forth and fifth senses of theology. In a way, the strength and the weakness of his own theology-in fact, this theology is a postmodern philosophy of religion, religion being identified with orthodox Christianity, see the sixth sense of philosophy, 32-are very similar to the strength and the weakness of the (postmodern, modern, and antimodern) great Barth himself. As the reader may understand if he reads my book on Barth (Müller, 2005), for me it is rather a compliment, but, like every Protestant compliment maybe, a paradoxical one. To be clear I think that the price to pay for such an understanding both of secularity and of theology is very high: secularity — with all the splendid efforts of rational modern philosophy from Kant to Weischedel or Ricoeur-does not find a proper recognition of its human project and theology. Engelhardt's Christianity, on the other side, is reduced to "orthodox" faithfulness and repetition, without being able to integrate the beauty of the world, the meaning of history, and the creativity of human rationality and interpretation in his own theory. At the end, the victims are Christianity, faith, and church, more and more isolated and separated from the whole reality of the good creation of God and of the whole reality of the ambivalent human history.

When we speak with Gogarten (or Weber, Blumenberg, or Gauchet) of the meaning of secularization, we consider a social, cultural framework, and not the particular and subjective engagement of individuals, which can be of course totally different from one person to another living in the same framework. The other side of secularization lies of course in the practical realities of daily religious life. As secularization and secularity mean only a formal framework and not an ideological one, nobody is forced to adhere to any particular interpretation of such a framework. In the same way, the notion of disenchantment, by Weber and Gauchet, has no a priori substantial signification and it must not be subjected to direct theological objections. The sociological thesis of secularity and disenchantment has in principle no influence on the fact that in our contemporary societies some people give preference 
to mere secularism and others to a more open understanding of secularity. If for instance we do not appreciate the way a special State or political instance wish to solve the problem of religious freedom and the problem of the respect of our personal religious beliefs in public and private schools, our personal choice, in any direction, remains part of the social and cultural framework of the modern, secularized, and secular world. Both religious confession and atheism can and must exist together in the same framework. That also positively means that the State has to remain religiously and ideologically neutral, a position that is to be seen as an advantage and a guarantee and not a disadvantage for the believers of any religious community as it is also, of course, for agnostics or atheists. The neutrality of the State results not only from a political necessity but also from the theological request to respect the free dimension of any faith. It also means that we have to refuse two antagonist but symmetrical positions: the secularist position, which tries to expel every religious symbols (cross, bells) from any public spot, and the traditionalist and fundamentalist position, which presumes to impose religious symbols or a particular reading of the Bible (creationism) as obligatory for State, schools, or teaching.

Objectively spoken, the chances of Christian life, faith, and churches in Switzerland are connected with the fact that, till now, the conception of an "open laicity" or neutral secularity has won out against the opposite version of a secularist, narrow-minded version of laicism or secularism. Open laicity, or secularity, means here, quite in keeping with a postmodern setting, the acceptance of the plurality of religions in a democratic society. Now it is true that, as a protestant theologian and ethicist, I also find this preferable from a Christian perspective, as I have tried to explain above. Of course, like any Christian and any church, I consider that we have to increase the number and the quality Christian believers in Switzerland and in the world as a whole. But this missionary and theological conviction does not imply, in my opinion, that we should criticize the present State and the contemporary society for not to being enough, or fully, Christian! There is a lot of sound theological (and very Trinitarian) argument in favor of a position like mine: (a) from the point of view of creation, every human being is a creature of God, without any religious discrimination; the particular fact that one is a Jew, a Christian, a Muslim, a Buddhist, or an atheist, for instance, does not repudiate this creational truth; (b) from a christological and soteriological point of view, the appeal of Jesus to follow him and to become his disciple is a free proposal and not a rational or sociological necessity; till the end of the world, Jesus will continue to call men and women to believe in him and in his Father, and so we must be ready to accept positively the permanent tension between Christian faith as a personal move, Christianity as a world phenomenon, churches as free gathering of believers, and the secular world as the open theatre of the glory of God (to paraphrase a famous thesis of John Calvin); (c) from a pneumatological perspective, the Holy Spirit is given 
constantly anew to every Christian and church and has nothing to do with an objective, rational, or theocratic domination of the secular word, of State or school; (d) last but not least, from an eschatological perspective, the present world, as the creation of God and the theatre of his glory, still remains the imperfect world of secularity and immanence and has not yet fully integrated the complete power and light of the eternal Kingdom of God; this eschatological tension gives us, as imperfect Christians and as imperfect Christian churches, the chance to look and to act forwards in the direction of the perfection and holiness of the triune God. When I speak here of imperfect Christians and of imperfect churches, I do not just think of my own Protestant tradition, but I really include, theologically, all Christians and all churches, whose members remain, in sound Protestant ecclesiology and theology, saints and sinners at the same time, till the ultimate manifestation of the Kingdom of God. This contention is not to be seen as an absence of catholicity or universality from the part of Protestant Christians and churches but is the positive and critical contribution of Protestant theology and ecclesiogy to a concrete, real, and respectful universality of all Christians. Without integrating seriously this contribution, churches like the Roman Catholic or the orthodox ones remain as one sided, exclusive, and potentially heretic (in the original sense of selective) as are also all Protestant denominations when they consider their contribution to be the whole and only truth. We really need each other to be fully Christian! In other words, take theological differences seriously (Engelhardt, 2007) means (a) to recognize the limits of my own theological constructions, Catholic, Orthodox, or Protestant; (b) to confess and to recognize that we are unable to reach the whole truth of the Gospel, if we stay locked in the selfishness and pride of our own orthodoxy. Protestant theology has, also, known periods of rigid and rigorous orthodoxy (the Protestant orthodoxy of the sixteenth to seventeenth centuries, Barthian neoorthodoxy, a very narrow and selfish reception of the much more open or controversial theology of Barth, and even "liberal orthodoxy," in the sense of a noncritical, secularist, and modernist affirmation of theological liberalism). These phenomena also give me every reason not to accept any kind of theological or dogmatic or moral orthodoxy. And this is also why I cannot accept today's neoorthodoxy of pope Benedict XVI, whose conservatism and authoritarianism I do not support at all. Contrary to the alleged objective complicity between him and me that Tristram Engelhardt presupposes, I consider that "flattery" as deriving from a deep misunderstanding of my own convictions and theology (even if it is true that, in the question of the links between faith and reason, I find the Thomist model more coherent and convincing than the antimodern fideism we can find today in the so-called postmodern philosophies and theologies of many communitarians). ${ }^{4}$

The only way to live together in a nonviolent and tolerant manner is to sustain such a democratic framework. In the nineteenth century, Switzerland 
had difficult times of religious intolerance, specially between Protestants and Catholics. Constructive ecumenism, that means religious peace integrating intensive confrontation of minds, theologies, and ethical convictions, has played a very important and positive role to overcome this dangerous situation and to avoid civil war. But today Switzerland is no more just a biconfessional country. Judaism, Islam, and other religions are becoming more and more visible. On the other hand, secularism is also developing in individuals' lives and in the public sphere. For these reasons, we can observe a growth of the political idea of laicity and religious neutrality, as a formal tool of mutual respect and consideration.

In this context, it is necessary to understand that plurality has by no means in Switzerland, as is probably also the case in most of the Western European countries, a negative, ideological meaning. Political, cultural, ethical, and religious plurality is not to be confused with poor pluralism or relativism. It means a practical and formal agreement not to use violence against the convictions of the citizen living in a same democratic and impartial State. It recognizes the right of churches and believers not only to exist and develop but also to contribute to the public debate with no intellectual or ethical restrictions.

Surely, the discussion is not yet at an end. There are still strong partisans of secularism and laicism. Therefore, the challenge remains difficult for churches and Christians in Switzerland too: many members of the evangelical churches, just as an important part of the Catholic Church, seem to prefer an attitude of radical opposition to the secular city. With others, both Protestant and Catholic, I personally have strong preference for a more constructive and promise-orienting attitude, based on another theology and an other way of doing applied ethics: radical questioning of secularism and laicism does not mean refusal of open laicity and plural, respectful secularity. In order to avoid what I call poor secularism, we need a thick, rich, and dynamic approach of Christian faith and action in the midst of a plural, open, and democratic society.

As a Swiss Presbyterian theologian with a first formation in dogmatics and hermeneutics, that means also under a strong influence of Lutheran and not only Reformed or Calvinist theology and ideas (see Müller, 2007a), I try to find a balance between my own engagements in a certain tradition of faith and practice and the necessity to be present and active in the public sphere of an open, secular country. As shown above, I do not see any opposition between a clear and public affirmation of faith by churches and believers and the defense of a secular and plural society, in the framework of a democratic State constantly questioned and challenged by responsible and free citizens.

In my theological and ecclesiological view, the Church (I mean the universal, Catholic Church of Jesus Christ, church of all believers and not a structure belonging to a certain particular tradition, like Greek Orthodox, Russian Orthodox, Roman Catholic, or Calvinistic for instance) is not a club of moral and religious friends, but a surprising and graceful gathering of moral, political, and 
religious strangers, who accept to confess a same God and a same faith in a absolutely paradoxical way, because the concrete members of this over-visible and over-divided invisible and unique Church appear to be politically, morally, spiritually, and theologically radically diverse and heterogeneous. The Church of Jesus Christ is not a cocoon of well-thinking and well-behaving "bourgeois,"

a club of friends, but a impossible and graceful coalition of justified sinners (as Martin Luther once said in his completely orthodox reading of Saint Paul).

Therefore, I cannot recognize in the objections of Engelhardt to my own theological approach a correct description of my own personal convictions and engagements nor a correct theological and intellectual description of the convictions, sociological realities, and pastoral and ethical practices of the modern Protestantism. To pretend that Protestantism has no sense of Church is to impose a certain dogmatic vision of church to the other Christian brothers and sisters. On this particular point, contemporary modern Protestants may be very anxious because they observe and feel a common alliance of Roman Catholicism, all currents of orthodoxy, high church Anglicanism, and conservative evangelicalism to impose a narrow-minded view of faith, church, and ethics. We Protestants do not see a big difference, to be honest, between the authoritarian self-sufficiency of the new pope and the self-sufficiency of antimodern and antirational traditional orthodoxy or evangelical fundamentalism. All these trends of self-affirmation represent a spiritual and political danger for the world of today, which needs social openness and solidarity, liberal tolerance, and recognition of the rights of the others.

This perspective has many consequences in the way Swiss bioethicists may discuss the different practical questions, which appear on the public agenda. For instance, we have approved, as reformed Protestants, a new legislation on abortion and a new legislation on homosexual partnership, but we have never been ready to minimalize the gravity of abortion or to confuse homosexual partnership with marriage. In the same way, we have opposed to give gay and lesbian couples access to parenthood. We know that these lines are thin and grey. But we are convinced that it is on this secular and instable line that we have to attest what is the personal and spiritual meaning of the Gospel for today's men and women.

\section{NOTES}

1. I suspect part of my theological and intellectual disagreement with Engelhardt has to do with the sociological and cultural gap between Western Europe (where I live) and the United States. For instance, I presuppose that the political liberalism (in the sense of Rawls and Habermas also) is very positive and that we live in Europe in a very good context of discussion, where we are able, for instance, to contest the secularist interpretation of reality because this interpretation, although dominant, is not the only one to be accepted in our pluralistic society. But for sure, the reasons for my debate with Engelhardt are more complex: I also disagree with him on the conception of theology in connection with faith, reason, and hermeneutics. This dissent has partly to do with our different confessional backgrounds (Orthodox or Reformed-Presbyterian), but the confession is not all. I also personally disagree both with liberals 
and evangelical in my own reformed tradition, and I do believe and hope that Orthodox theology has a greater internal plurality than many people suggest.

2. These five senses of theology are (1) "noetic-experiential knowledge," (2) "prayerful reading of the record of revelation" (e.g., in the Bible) "within the noetic parameters known through theology in the first sense," (3) "discursive reflection" on theology one and two, (4) "discursive and speculative philosophical reflection concerning God," (5) "discursive and speculative reflection on the Bible," "tradition and on dogmatic statements ..., as well as on 'religious experience'” (viz. Engelhardt, 2007).

3. The French term "laïcisme" is usually translated into the English "secularism." The French "laicité," by contrast, has no simple or evident English counterpart: it must be circumscribed as "neutrality of the State towards every religion" or according to the proposal of Badini Confalonieri (2002): "the recognition of the distinction between State and church, as institutions having authority in different areas." In order to avoid the awkwardness of this expression, I used the recent English neologism "laicity."

4. On the move from Hauerwas to Engelhardt, see Müller (2007b, 2007c) and Müller et al. (2007).

\section{REFERENCES}

Badini Confalonieri, G. 2002. Il principio di laicità dello stato e le immagini sacre nei locali pubblici: Commento alla sentenza della Corte di Cassazione penale n. 4273 del 1o marzo 2000 in Revue I Tre Anelli-Les Trois Anneaux, 4, 87-96 [The Principle of the Laicity of the State and Sacred Images in Public Places: A Comment on Decision No. 4273 of the Italian Court of Penal Cassation on March 1, 2000]. Available: http://www.lonergan.org/dialogue_partners/badini/principle_of_the_laicity_of_the.htm. (Accessed March 6, 2009).

Bühler, P. 2007. La séparation des Eglises et de l'Etat. Enjeux théologiques. Etudes Théologiques et Religieuses 821:3-16.

Campiche, R. 2004. Les deux visages de la religion. Fascination et Désenchantement. Genève, Switzerland: Labor et Fides.

Engelhardt, H. T., Jr. 2007. Why ecumenism fails: Taking theological differences seriously. Christian Bioethics 13:25-51.

Gogarten, F. 1987. Verhängnis und Hoffnung der Neuzeit. Die Säkularisierung as theologisches Problem, 2nd ed. Gütersloh, Germany: Gütersloher Verlagshaus (Siebenstern Taschenbücher).

Müller, D. 2005. Karl Barth, Paris, France: Le Cerf.

2007a. The original risk: Over-theologizing ethics and under-theologizing sin. Christian Bioethics 13:7-23.

2007b. In D. Müller, M. Sherwin, N. Maillard, and C. S. Titus (eds). Sujet éthique fragile et communauté sensible à la transcendance. Sujet moral et communauté (pp. 59-78), Fribourg, Switzerland: Academic Press.

- 2007c. Scolastique néo-barthienne, audace interprétative et nouvelles tâches de la théologie et de l'éthique. Revue de Théologie et de Philosophie 1393:249-57.

. 2008. The role and the influence of religions in bioethics. In Global bioethics, eds. Ronald M. Green, Aine Donovan, and Steven A. Jauss, 334-56. Oxford: Oxford University Press.

D. Müller, M. Sherwin, N. Maillard, and C. S. Titus (eds). 2007. Sujet moral et communauté. Fribourg, Switzerland: Academic Press. 